\title{
EFFECT OF DIFFERENT SOURCES OF ORGANIC FERTILIZERS ON VEGETATIVE GROWTH, YIELD AND STORABILITY OF LETTUCE PLANTS
}

\author{
OMAIMA O. MOHAMMED' ${ }^{1}$, M. A. SALEH ${ }^{1}$ and MANAL A. MANDOUR ${ }^{2}$ \\ 1- Postharvest of Vegetable Crops Dept., Hort. Res. Inst., ARC, Egypt. \\ 2- Central Lab. for Organic Agric., ARC, Egypt.
}

(Manuscript received 2 May 2019)

\begin{abstract}
1 his investigation was carried out during two winter seasons of 2016/2017 and 2017/2018 at the Agricultural Research Farm, ElKassasien Hort. Res. Station, Ismalia Governorate, Egypt, to study the effect of different sources of organic fertilizers, i.e. chicken manure, farmyard manure (FYM), compost manure and the mixture of them as compared to mineral fertilizer on vegetative growth, fresh and dry weight per plant, root system, yield and its components of cv. Balady (Local lettuce cultivar) grown under sandy soil conditions.It aimed also to study the effect of the abovementioned treatments on storability of lettuce plants during storage at $0^{\circ} \mathrm{C}$ and $90-95 \% \mathrm{RH}$. Fertilization of lettuce plants with chicken manure at $7.5 \mathrm{~m}^{3} / \mathrm{fed}$. or with the mixture of chicken at $2.5 \mathrm{~m}^{3}$ plus FYM at $5 \mathrm{~m}^{3}$ plus compost manure at $3.7 \mathrm{~m}^{3} /$ fed. significantly increased vegetative growth, fresh and dry weight of different organs per plant, root system per plant and water content as well as yield and it's components, while decreased nitrate content without significant differences between them in most cases.Using organic manure the mixture of chicken manure at 2.5 $\mathrm{m}^{3}$ plus farmyard manure at $5 \mathrm{~m}^{3}$ plus compost manure at $3.7 \mathrm{~m}^{3} / \mathrm{fed}$. or chicken manure improve storability of lettuce plants by reducing weight loss and polyphenol oxidase (PPO) activity, maintained chlorophyll and total phenolic contents during storage and gave plants with good appearance after 12 days of storage for chicken manure and after 16 days for mixture treatment.

Key words: Lettuce plants, chicken manure, compost manure, farmyard manure, growth, root system, yield and storability as well as phenolic contents.
\end{abstract}

\section{INTRODUCTION}

Lettuce (Lactuca sativa L.) is an annual plant of the family Asteraceae and one of the most popular among leafy vegetables and salad crops in all world countries grown in cool season. In Egypt, lettuce is an important vegetable crop for both farmers and consumers. For farmers, it is considered as a fast cash crop in the winter season. For consumers, lettuce is eaten fresh and salad, where it is rich in vitamins and minerals. Also, lettuce grown in Egypt for local consumption and exportation.

Newly reclaimed sandy soil had unfavorable physical, chemical and biological conditions, high $\mathrm{pH}$, low water holding capacity and high ability to erosion and scarcity of amended water. Thus, addition of organic manures to sandy soil is very important to increase soil acidity and soil exchange capacity, provide energy for micro-organisms 
activity, increase water holding capacity and buffering of the soil infiltration (Hsieh and Hsu, 1993). Organic manure also, contains many species of living organisms which release phyto-hormones as GA, IAA and CYT which stimulate plant growth (Reynders and Vlassak, 1982).

Using mineral fertilizers (NPK) without rationalization may cause environmental pollution as well as contaminate the underground water. Therefore, there was a great attention to use organic fertilizers in the production of vegetables in order to reduce the contamination of plant and soil with different elements, to reduce the usage of mineral fertilizers, to produce clean crop and also to improve the soil properties. Moreover, reducing environmental pollution through decreasing the amount of chemical fertilizers is of great demand nowadays for human, safety and reducing air and water pollution (Ahmed, 2013).Thus, fertilization lettuce plants with Vermicompost ( $4 \mathrm{t} / \mathrm{ha}$ ) plus chemical fertilizer recorded higher values for plant height, leaf area, number of leaves plant, average leaf weight, leaf weight plant, leaf yield plot, and leaf yield ha. (Rather et al., 2018). Application of $13 \mathrm{t} /$ ha organic fertilizer significantly increased leaf size (length and breadth) of lettuce; this treatment also increased fresh weight, dry weight and yield (Hossain and Ryu 2017).

Melese (2016) revealed that farm yard manure with the rate of $3.3 \mathrm{~kg}$ (15 $\mathrm{t} / \mathrm{ha}$ ) highly increased the yield and yield components (plant height, leaf size, number of leaf per plant, fresh leaf weight, root depth and number of root per plant). Reis et al. (2014) suggested the amount of $3.0 \mathrm{~kg}$ compost $\mathrm{m}^{2}$ (30 Ton/ha) as the best application rate, due to the higher growth and lettuce yield, and the lower content of nitrate.

Chicken manure levels significantly affected growth, yield and nutritional quality of lettuce, a trend of superiority of the different level of chicken manure application was observed as lettuce provided with $60 \mathrm{Ton} / \mathrm{ha}$ exhibited higher values in number of leaves, plant height, marketable yield and mean leaf dry mass (Masarirambi et al., 2012).

After harvesting, lettuce plants are a highly perishable crop due to its high moisture content, shriveling associated to rapid loss of weight, high respiration rate and short life. The major causes of quality loss of lettuce plants are dehydration, leaf discoloration and decay (similar to lettuce plants). There was a considerable increase in weight loss percentage of stored lettuce plants with prolonging the storage period (Bardisi et al., 2013).

Concerning the effect of organic fertilization on fruit storability, El-Sheikh and Salama (1997) observed that chicken manure improved tomato fruit storability by decrease weight loss and decay percentage and maintained the fruit quality during 
storage when compared with mineral fertilizer treatment. Also, Abd El-Rhman and Hosney (2001) found that using organic fertilization (chicken and cattle manures) improved eggplant fruit storability and maintained fruit quality during storage. This improvement was much pronounced at the application of chicken manure.

Thus, this work aimed to investigate the effect of different sources of organic fertilizers on vegetative growth, fresh and dry weight, root system, nitrate content and yield as well as storability of lettuce plants grown under sandy soil conditions.

\section{MATERIALS AND METHODS}

\section{Field experiment:}

The field experiments was carried out during the winter seasons of 2016/2017 and 2017/2018 at the Agricultural Research Farm, El-Kassasien Hort. Res. Station, Ismalia Governorate, Egypt, to study the effect of different sources of organic fertilizers, i.e. chicken manure, farmyard manure (FYM), compost manure and the mixture of them, as compared to mineral fertilizer on vegetative growth, fresh and dry weight, root system, yield, and storability of cv. Balady lettuce (Local cultivar) plants grown under sandy soil conditions during cold storage.

This experiment included five treatments as follows:

Mineral fertilizer at $40 \mathrm{~kg} \mathrm{~N} /$ fed.,chicken manure at a rate of $7.5 \mathrm{~m}^{3} / \mathrm{fed}$.,farmyard manure at a rate of $15 \mathrm{~m}^{3} / \mathrm{fed}$., and compost manure at a rate of $11 \mathrm{~m}^{3} / \mathrm{fed}$., as well as a mixture of chicken $\left(2.5 \mathrm{~m}^{3}\right)$ plusfarmyard $\left(5 \mathrm{~m}^{3}\right)$ and compost manure $\left(3.7 \mathrm{~m}^{3}\right)$ per feddan, with knowing that these rates contained the same nitrogen level (40 kg N nearly) according to the chemical analysis of the used organic manure). These treatments were distributed in a randomized complete block design with three replications.

Table 1. The physical and chemical properties of the experimental soil field

\begin{tabular}{|c|c|c|}
\hline Properties & $2016 / 2017$ & $2017 / 2018$ \\
\hline \multicolumn{3}{|c|}{ Physical Properties (\%) } \\
\hline Sand & 96.5 & 95.6 \\
\hline Silt & 1.7 & 1.6 \\
\hline Clay & 1.8 & 2.8 \\
\hline Texture & sandy & sandy \\
\hline \multicolumn{3}{|c|}{ Chemical properties } \\
\hline Organic matter (\%) & 0.06 & 0.08 \\
\hline $\mathrm{pH}$ & 8.1 & 8.1 \\
\hline Available N & 5.4 & 6.9 \\
\hline Available $P \quad(p p m)$ & 5.5 & 6.2 \\
\hline Available K (ppm) & 52 & 64 \\
\hline Calcium carbonate $(\%)$ & 0.18 & 0.26 \\
\hline
\end{tabular}


The experimental unit area was $12.6 \mathrm{~m}^{2}$, every plot consisted of six rows $3.5 \mathrm{~m}$ in length and $60 \mathrm{~cm}$ in width with about 210 plants in every plot. Lettuce seeds were sown in nursery bed on $4^{\text {th }}$ and $6^{\text {th }}$ of Octoberin both seasons and then transplants of nearly 40 days were transplanted on $14^{\text {th }}$ and $16^{\text {th }}$ of November in the permanent field on both sides of dripper lines at $20 \mathrm{~cm}$ between plants. Two rows $\left(4.2 \mathrm{~m}^{2}\right)$ were used to measure vegetative growth traits and the other four rows $\left(8.4 \mathrm{~m}^{2}\right)$ were used for estimating yield and its components and storability of plants. The chemical analysis of used organic manures was scheduled in schedule 1 . Also, nitrogen amount in each of one $\mathrm{m}^{3}$ of different organic manure was shown in schedule 2 .

Schedule 1. Chemical analysis of used organic manure during2016/2017 and $2017 / 2018$ seasons

\begin{tabular}{|c|c|c|c|c|c|c|}
\hline \multirow{3}{*}{$\begin{array}{l}\begin{array}{l}\text { Type of } \\
\text { analysis }\end{array} \\
\text { Season } \\
\end{array}$} & \multicolumn{6}{|c|}{ Kind of manure } \\
\hline & \multicolumn{2}{|c|}{ Chicken } & \multicolumn{2}{|c|}{ FYM } & \multicolumn{2}{|c|}{ Compost } \\
\hline & $1^{\mathrm{ST}}$ & $2^{\mathrm{ND}}$ & $1^{\text {ST }}$ & $2^{\mathrm{ND}}$ & $1^{\mathrm{ST}}$ & $2^{\mathrm{ND}}$ \\
\hline O.M.\% & 59.78 & 58.37 & 30.32 & 33.38 & 47.45 & 47.88 \\
\hline N\% & 2.21 & 2.29 & 0.55 & 0.61 & 0.98 & 1.02 \\
\hline $\mathbf{P} \%$ & 0.51 & 0.53 & 0.31 & 0.36 & 0.45 & 0.51 \\
\hline K\% & 1.28 & 1.33 & 0.93 & 0.96 & 1.08 & 1.13 \\
\hline \multicolumn{7}{|c|}{ Schedule 2. Nitrogen amount in different organic manure $\left(\mathrm{Kg} / \mathrm{m}^{3}\right)$} \\
\hline \multicolumn{3}{|c|}{ Kind of manure } & \multicolumn{2}{|c|}{$2016 / 2017$} & \multicolumn{2}{|c|}{$2017 / 2018$} \\
\hline \multicolumn{2}{|c|}{$1 \mathbf{m}^{3}$ Chicken } & $(243 \mathrm{Kq})$ & \multicolumn{2}{|c|}{5.37} & \multicolumn{2}{|c|}{5.49} \\
\hline $1 \mathbf{m}^{3} \mathbf{F}$ & \multicolumn{2}{|c|}{$(486 \mathrm{Kg})$} & \multicolumn{2}{|c|}{2.67} & \multicolumn{2}{|c|}{2.96} \\
\hline \multicolumn{3}{|c|}{$1 \mathrm{~m}^{3}$ Compost $(380 \mathrm{~kg})$} & \multicolumn{2}{|c|}{3.72} & \multicolumn{2}{|c|}{3.87} \\
\hline
\end{tabular}

All amounts of organic fertilizers were added during soil preparation before sowing, whereas mineral nitrogen fertilizer were divided into three portions, the first was added at 15 days after transplanting and the others two portions were added at 30 and 45 days after transplanting. All plots received equal amounts of FYM at a rate of $20 \mathrm{~m}^{3} /$ fad. during soil preparation, the other recommended agricultural practices for commercial lettuce production were practiced.

\section{Data Recorded}

\section{Vegetative Growth}

A random sample of three plants from every experimental unit was taken after 60 days from transplanting to investigate the following growth parameters: Plant height, number of leaves /plant, leaf area/plant, fresh weight of stem, fresh weight of leaves and total fresh weight/plant (leaves plus stem). 
Dry Weight: Different plant parts were oven dried at $70^{\circ} \mathrm{C}$ till constant weight, and the following data were recorded: Dry weight of stem, leaves and total dry weight/plant (stem plus leaves).

Water content \%: It was measured according to the following equation: [(fresh weight - dry weight)/fresh weight] x100

Root system traits: The root of lettuce plants were carefully separated by washing the sand from them and roots were placed in a flat glass dish containing a little amount of water. Roots were straighter with forceps, so that they cannot overlap and were held in position, and the following data were recorded per root: root length, fresh and dry weight of root, and root volume.

Nitrate content: It was determined on the basis of dry weight according to the method described by Cafado et al. (1975).

Yield and its Components: At harvesting time (about 70 days after transplanting) all plants from each plot were harvested to measure average head fresh weight, yield/plot and total yield/fad.

\section{Storage Experiment:}

This experiment was conducted to study the effect of different sources of organic fertilizers as compared to mineral fertilizer on keeping quality of lettuce plants during storage period.

\section{Plant material and treatments:}

In this experiment, Lettuce (Lactuca sativa L.) CV. Balady plants of the field experiment were harvested at suitable maturity stage of marketing on January $23^{\text {rd }}$ and $25^{\text {th }}$ (70 days from transplanting) in the first and second season, respectively.

Uncompacted and non-uniform plants were eliminated and chose healthy with dark green outer leaves, symmetrical in shape and good ones of plants were transferred directly to the laboratory of Postharvest Handling of Vegetable Crops Department, Horticulture Research Institute, Agriculture Research Center, Giza, Egypt. Plants were trimmed (leaf tips and root cut) and every plant served as one replicate was packed individually in macro perforated polypropalyne bags with pin holes (one head/polypropalyne bag) were used.

Sixteen replications were prepared for each treatment and packed in carton boxes (each box contained three bags and stored at $0^{\circ} \mathrm{C} \pm 1^{\circ} \mathrm{C}$ and $95 \%$ relative humidity. Four samples of lettuce plants were randomly taken at 4, 8, 12 and 16 days from storage period to determine the following data:

Weight loss: It was measured as the percentage of loss from the initial weight. 
General appearance: It was determined according to the following score system:9 = excellent, $7=$ good, $5=$ fair, $3=$ poor, and $1=$ unusable. This scale depends on vegetative defects such as leaf wilting, and leaf discoloration.

Total chlorophyll: It was measured in fresh leaves by using Minolta chlorophyll meter SPAD-501as SPAD units.

Polyphenol oxidase (PPO) activity: polyphenol oxidase was determined by the colorimetric modified method of Dogăn et al. (2002).

Total phenolic: The phenolic content was determined by the colorimetric modified method of Velioglu et al. (1998) using Folin-Ciocalteu reagent.

Statistical Analysis: The obtained data of the first and second experiments were statistically analyzed by Snedecor and Cochran (1982) and difference among treatments were statistically compared using Duncan's multiple range test at a level of 0.05 using the CoStat v6.4 program.

\section{RESULTS AND DISCUSSION}

\section{Field experiment}

\section{Root stem}

Data presented in Table (2) show that there were significant differences among the tested organic manures and mineral fertilization in root system of lettuce plants expressed asroot length, fresh and dry weight of root per plant as well as root volume.Such data revealed that using chicken manure at a rate of $7.5 \mathrm{~m}^{3} / \mathrm{fed}$. significantly increased all different root system parameters during both seasons of growth followed by mineral fertilization in case of root length only, while using the mixture of the three manures (chicken manure at $2.5 \mathrm{~m}^{3}$ plus farmyard manure at 5 $\mathrm{m}^{3}$ plus compost manure at $3.7 \mathrm{~m}^{3} / \mathrm{fed}$.) ranked the second in all root system measurements and without significant differences between them and chicken manure in case of root dry weight merely.

On the contrary, the lowest values in all measured root system traits were recorded in case of using farmyard manure (FYM) at a rate of $15 \mathrm{~m}^{3} /$ fed. The stimulate effect of chicken manure and the mixture of three manures on root system of lettuce plant by improved physical environment and added supply of nutrients and proliferous root system developed early resulting and better absorption of water and nutrients (Rather et al., 2018). Organic manures also produced the highest average root length because it ensures favorable condition for the growth of lettuce.In this respect,similar findings were reported by Melese (2016)and Masarirambi et al., (2012) on lettuce. 


\section{Vegetative Growth:}

Data presented in Table 3 showed that there were significant differences among the tested organic manures and mineral fertilizer on morphological characters of lettuce plants; i.e., plant height, number of leaves per plant and leaf area. Such data reveal that using chicken manure at a rate of $7.5 \mathrm{~m}^{3} / \mathrm{fed}$. significantly increased all different vegetative growth parameters during both seasons of growth followed by fertilization of the mixture of chicken manure $\left(2.5 \mathrm{~m}^{3} / \mathrm{fed}\right.$.) plus farmyard manure (5 $\mathrm{m}^{3} / \mathrm{fed}$.) plus compost manure ( $3.7 \mathrm{~m}^{3} /$ fed.) without significant differences between them in most cases.

On the contrary, the lowest values in all measured growth traits were recorded in case of using farmyard manure (FYM) at a rate of $15 \mathrm{~m}^{3} /$ fed. during both seasons of study. The enhancing effect of chicken manure and mixtures manures on plant growth may be due to that such organic manures play a role as soil amendment which improve water capacity of sandy soils and increase macro and micro elements availability in the rhizosphere around root system which in turn increased plant growth (Ahmed, 2013) also this could be attributed to large quantities of available phosphorus and potassium per kilogram in the chicken manure (Schedule 1).

Obtained results are in conformity with those of Masarirambi et al. (2012) on lettuce.

Table 2. Effect of different sources of organic fertilizers on root system of lettuce plants at 60 days after transplanting during 2016/2017 and $2017 / 2018$ seasons.

\begin{tabular}{|c|c|c|c|c|c|c|c|c|}
\hline \multirow{2}{*}{ Treatments } & \multicolumn{2}{|c|}{ Root length (cm) } & \multicolumn{2}{|c|}{$\begin{array}{c}\text { Root fresh weight } \\
\text { (g) }\end{array}$} & \multicolumn{2}{|c|}{$\begin{array}{c}\text { Root dry weight } \\
\text { (g) }\end{array}$} & \multicolumn{2}{|c|}{$\begin{array}{c}\text { Root volume } \\
\left(\mathrm{cm}^{3}\right)\end{array}$} \\
\hline & $\begin{array}{c}1^{\text {st }} \\
\text { season }\end{array}$ & $\begin{array}{c}2^{\text {nd }} \\
\text { season }\end{array}$ & $\begin{array}{c}1^{\text {st }} \\
\text { season }\end{array}$ & $\begin{array}{c}2^{\text {nd }} \\
\text { season }\end{array}$ & $\begin{array}{c}1^{\text {st }} \\
\text { season }\end{array}$ & $\begin{array}{c}2^{\text {nd }} \\
\text { season }\end{array}$ & $\begin{array}{c}1^{\text {st }} \\
\text { season } \\
\end{array}$ & $\begin{array}{c}2^{\text {nd }} \\
\text { season }\end{array}$ \\
\hline $\begin{array}{l}\text { Mineral } \\
\text { fertilizer }\end{array}$ & $21.43 a$ & $19.68 \mathrm{a}$ & $38.2 \mathrm{~cd}$ & $31.3 d$ & $8.58 b c$ & $7.54 \mathrm{c}$ & $47.8 \mathrm{c}$ & $40.4 d$ \\
\hline $\begin{array}{l}\text { Chicken } \\
\text { manure }\end{array}$ & $20.62 a$ & $20.07 a$ & $44.8 \mathrm{a}$ & $41.2 \mathrm{a}$ & $10.17 a$ & $9.97 a$ & $56.0 a$ & $49.1 \mathrm{a}$ \\
\hline FYM manure & $15.28 d$ & $14.16 d$ & $37.5 d$ & $31.4 d$ & $8.46 c$ & $7.58 \mathrm{c}$ & $46.9 d$ & $40.5 d$ \\
\hline $\begin{array}{l}\text { Compost } \\
\text { manure }\end{array}$ & $17.12 \mathrm{c}$ & $14.83 c$ & $38.9 c$ & $37.7 c$ & $8.79 b c$ & $9.07 b$ & $48.6 c$ & $43.6 c$ \\
\hline $\begin{array}{l}\text { Mixture } \\
(2+3+4)\end{array}$ & $18.31 b$ & $16.39 b$ & $41.6 \mathrm{~b}$ & $39.8 b$ & $9.38 \mathrm{ab}$ & $9.63 a b$ & $52.4 b$ & $46.2 b$ \\
\hline
\end{tabular}

Values having the same alphabetical letter (s) did not significantly differ at 0.05 level of significance according to Duncan's multiple range test.

* Mixture (chicken manure at $2.5 \mathrm{~m}^{3}$ plus FYM at $5 \mathrm{~m}^{3}$ plus compost manure at $3.7 \mathrm{~m}^{3} / \mathrm{fed}$.) 
Table 3. Effect of different sources of organic fertilizers on vegetative growth of lettuce plants at 60 days after transplanting during $2016 / 2017$ and $2017 / 2018$ seasons.

\begin{tabular}{|l|c|l|l|l|l|l|}
\hline \multirow{2}{*}{ Growth } & \multicolumn{2}{|c|}{ Plant height (cm) } & \multicolumn{2}{c|}{ No. of leaves/plant } & \multicolumn{2}{c|}{$\begin{array}{l}\text { Leaf area } \\
\left.\text { (cm }{ }^{2} / \text { plant }\right)\end{array}$} \\
\cline { 2 - 7 } & $\begin{array}{l}\mathbf{1}^{\text {st }} \\
\text { season }\end{array}$ & $\begin{array}{l}\mathbf{2}^{\text {nd }} \\
\text { season }\end{array}$ & $\begin{array}{l}\mathbf{1}^{\text {st }} \\
\text { season }\end{array}$ & $\begin{array}{l}\mathbf{2}^{\text {nd }} \\
\text { season }\end{array}$ & $\begin{array}{l}\mathbf{1}^{\text {st }} \\
\text { season }\end{array}$ & $\begin{array}{l}\mathbf{2}^{\text {nd }} \\
\text { season }\end{array}$ \\
\hline Mineral fertilizer & $35.7 \mathrm{bc}$ & $41.7 \mathrm{bc}$ & $21.3 \mathrm{bc}$ & $24.3 \mathrm{~b}$ & $2256.1 \mathrm{c}$ & $2581.4 \mathrm{bc}$ \\
\hline Chicken manure & $39.7 \mathrm{a}$ & $44.7 \mathrm{a}$ & $24.3 \mathrm{a}$ & $27.3 \mathrm{a}$ & $2603.6 \mathrm{a}$ & $2926.3 \mathrm{a}$ \\
\hline FYM manure & $34.3 \mathrm{c}$ & $40.3 \mathrm{c}$ & $20.0 \mathrm{c}$ & $23.3 \mathrm{~b}$ & $2002.4 \mathrm{~d}$ & $2496.5 \mathrm{c}$ \\
\hline Compost manure & $36.3 \mathrm{bc}$ & $42.7 \mathrm{~b}$ & $21.3 \mathrm{bc}$ & $24.0 \mathrm{~b}$ & $2260.3 \mathrm{c}$ & $2544.0 \mathrm{bc}$ \\
\hline Mixture * & $37.7 \mathrm{ab}$ & $43.3 \mathrm{ab}$ & $22.7 \mathrm{ab}$ & $24.3 \mathrm{~b}$ & $2450.7 \mathrm{~b}$ & $2626.6 \mathrm{~b}$ \\
\hline
\end{tabular}

Values having the same alphabetical letter (s) did not significantly differ at 0.05 level of significance according to Duncan's multiple range test.

* Mixture (chicken manure at $2.5 \mathrm{~m}^{3}$ plus FYM at $5 \mathrm{~m}^{3}$ plus compost manure at $3.7 \mathrm{~m}^{3} / \mathrm{fed}$.)

\section{Fresh weight and water percentage:}

It is obvious from the data presented in Table 4 that fertilization lettuce plants with chicken manure at a rate of $7.5 \mathrm{~m}^{3} / \mathrm{fed}$. was the most favorable treatment for enhancing fresh weight significantly. In addition, using the mixture of the three manures ranked the second in all fresh weight measurements. On the contrary, the lowest values in all measured fresh weight traits were recorded in case of using FYM at a rate of $15 \mathrm{~m}^{3} / \mathrm{fed}$., the stimulative effect of chicken manure and mixture of the three manures on fresh weight of lettuce is a reflection of increasing root system and growth (Tables 2 and 3). These findings agree with those reported by Masarirambi et al, (2012) and Hossain and Ryu (2017) on lettuce.

Regarding water percentage, it is clear from the same data in Table 4 that fertilization lettuce plants with mineral fertilizer at $40 \mathrm{~kg} \mathrm{~N} / \mathrm{fed}$., was the superior treatment for increasing water percentage which gave 92.6 and $92.9 \%$ in the first and 2nd seasons, respectively. On the other side the lowest values in this respect were recorded in case of using the mixture of the three manures which gave 90.9 and $91.6 \%$ in the first and second seasons, respectively. 
Table 4. Effect of different sources of organic fertilizers on fresh weight and water percentage of lettuce plants at 60 days after transplanting during $2016 / 2017$ and $2017 / 2018$ seasons.

\begin{tabular}{|c|c|c|c|c|c|c|c|c|}
\hline \multirow{3}{*}{ Growth } & \multicolumn{6}{|c|}{ Fresh weight / plant (g) } & \multirow{2}{*}{\multicolumn{2}{|c|}{$\begin{array}{c}\text { Water } \\
\text { percentage }\end{array}$}} \\
\hline & \multicolumn{2}{|c|}{ leaves } & \multicolumn{2}{|c|}{ Stem } & \multicolumn{2}{|c|}{ total } & & \\
\hline & $\begin{array}{c}1^{\text {st }} \\
\text { season }\end{array}$ & $\begin{array}{c}2^{\text {nd }} \\
\text { season }\end{array}$ & $\begin{array}{c}1^{\text {st }} \\
\text { season }\end{array}$ & $\begin{array}{c}2^{\text {nd }} \\
\text { season }\end{array}$ & $\begin{array}{c}1^{\text {st }} \\
\text { season }\end{array}$ & $\begin{array}{c}2^{\text {nd }} \\
\text { season }\end{array}$ & $\begin{array}{c}1^{\text {st }} \\
\text { season }\end{array}$ & $\begin{array}{c}2^{\text {nd }} \\
\text { seaso } \\
n\end{array}$ \\
\hline $\begin{array}{l}\text { Mineral } \\
\text { fertilizer }\end{array}$ & $295.27 b$ & $242.16 c$ & $50.26 b$ & $38.26 c$ & $345.53 b$ & $280.42 c$ & $92.59 a$ & $92.86 a$ \\
\hline $\begin{array}{l}\text { Chicken } \\
\text { manure }\end{array}$ & $341.35 a$ & $348.27 a$ & $58.49 a$ & $51.23 a$ & $399.84 a$ & $399.50 a$ & $91.26 \mathrm{~b}$ & $91.97 b$ \\
\hline $\begin{array}{c}\text { FYM } \\
\text { manure }\end{array}$ & $286.02 b$ & $240.66 c$ & $48.86 \mathrm{~b}$ & $37.29 c$ & $334.88 b$ & $277.95 \mathrm{c}$ & $90.87 b$ & $91.76 \mathrm{~b}$ \\
\hline $\begin{array}{l}\text { Compost } \\
\text { manure }\end{array}$ & $297.43 b$ & $290.43 b$ & $51.08 b$ & $44.99 b$ & $348.51 b$ & $335.42 b$ & $91,12 b$ & $91.67 \mathrm{~b}$ \\
\hline Mixture * & $306.37 b$ & $298.55 b$ & $52.13 b$ & $46.69 b$ & $358.50 \mathrm{~b}$ & $345.24 b$ & $90.92 b$ & $91.60 \mathrm{~b}$ \\
\hline
\end{tabular}

Values having the same alphabetical letter (s) did not significantly differ at 0.05 level of significance according to Duncan's multiple range tests.

* Mixture (chicken manure at $2.5 \mathrm{~m}^{3}$ plus FYM at $5 \mathrm{~m}^{3}$ plus compost manure at $3.7 \mathrm{~m}^{3} / \mathrm{fed}$.)

\section{Dry weight and nitrate content:}

Data in Table (5) showed that the highest values of leaves, stems and total dry weight per plant were recorded as a result of fertilization lettuce plants with chicken manure followed by the mixture treatment then compost manure without significant differences among the three treatments in most cases, while the lowest values in this regard were recorded by the control treatment (mineral fertilizer).

The enhancing effect of the above mentioned treatments on dry weight may be due to the increasing palisade tissues of leaf and this intern enhance the photosynthesis process and translocation of photosynthesis assimilates rate and consequently increased vegetative growth and this reflected on increasing dry weight of plant (Arisha et al., 2015).

As for nitrate content, it is clear from the same data in Table 5 that fertilization lettuce plants with mineral fertilizer at $40 \mathrm{~kg} \mathrm{~N} / \mathrm{fed}$. was the superior treatment for increasing nitrate content which gave 71.70 and $74.36 \mathrm{mg} / \mathrm{kg}$ in the first and second seasons, respectively. On the contrary, the lowest values in this respect were recorded in case of using chicken manure that gave 33.01 and $29.01 \mathrm{mg} / \mathrm{kg}$ followed by mixture treatment which gave 39.01 and $37.01 \mathrm{mg} / \mathrm{kg}$ in the first and second seasons, respectively. 
Table 5. Effect of different sources of organic fertilizers on dry weight and nitrate content of lettuce plants at 60 days after transplanting during $2016 / 2017$ and $2017 / 2018$ seasons

\begin{tabular}{|c|c|c|c|c|c|c|c|c|}
\hline \multirow{2}{*}{ Growth } & \multicolumn{2}{|c|}{ Leaves } & \multicolumn{2}{|l|}{ stem } & \multicolumn{2}{|l|}{ total } & \multicolumn{2}{|c|}{$\mathrm{No}_{3}(\mathrm{mg} / \mathrm{kg})$} \\
\hline & $\begin{array}{l}1^{\text {st }} \\
\text { season }\end{array}$ & $\begin{array}{l}2^{\text {nd }} \\
\text { season }\end{array}$ & $\begin{array}{l}1^{\text {st }} \\
\text { season }\end{array}$ & $\begin{array}{l}2^{\text {nd }} \\
\text { season }\end{array}$ & $\begin{array}{l}1^{\text {st }} \\
\text { season }\end{array}$ & $\begin{array}{l}2^{\text {nd }} \\
\text { season }\end{array}$ & $\begin{array}{l}1^{\text {st }} \\
\text { season }\end{array}$ & $\begin{array}{l}2^{\text {nd }} \\
\text { season }\end{array}$ \\
\hline $\begin{array}{l}\text { Mineral } \\
\text { fertilizer }\end{array}$ & $14.11 \mathrm{c}$ & $11.19 \mathrm{c}$ & $11.48 \mathrm{~b}$ & $8.82 \mathrm{c}$ & $25.59 c$ & $20.01 d$ & $71.70 a$ & $74.36 a$ \\
\hline $\begin{array}{l}\text { Chicken } \\
\text { manure }\end{array}$ & $19.21 a$ & $18.89 a$ & $15.75 a$ & $13.20 \mathrm{a}$ & $34.96 a$ & $32.09 a$ & $33.01 \mathrm{c}$ & $29.01 d$ \\
\hline FYM manure & $16.43 b$ & $13.64 b c$ & $14.15 a b$ & $9.27 b c$ & $30.58 b$ & $22.91 \mathrm{c}$ & $49.02 b$ & $46.35 c$ \\
\hline $\begin{array}{l}\text { Compost } \\
\text { manure }\end{array}$ & 17.13ab & 16.07ab & 13.82ab & $11.86 a b$ & $30.95 b$ & $27.93 b$ & $49.02 b$ & $51.02 b$ \\
\hline Mixture * & 17.81ab & 16.81ab & $14.75 a$ & 12.18ab & $32.56 \mathrm{~b}$ & $28.99 b$ & $39.01 d$ & $37.01 \mathrm{e}$ \\
\hline
\end{tabular}

Values having the same alphabetical letter (s) did not significantly differ at 0.05 level of significance according to Duncan's multiple range test.

* Mixture (chicken manure at $2.5 \mathrm{~m}^{3}$ plus FYM at $5 \mathrm{~m}^{3}$ plus compost manure at $3.7 \mathrm{~m}^{3} / \mathrm{fed}$.)

\section{Yield and yield components:}

Data presented in Table 6 show that fertilization lettuce plants with chicken manure at $7.5 \mathrm{~m}^{3} / \mathrm{fed}$. was the superior treatment for increasing yield and its components which gave 495.8 and $478.4 \mathrm{~g}$ for average head fresh weight, 104.1 and $100.4 \mathrm{~kg}$ for yield per plot and 34.7 and 33.4 ton for total yield per feddan, while the increase in yield over control was 127.0 and $139.7 \%$ in the first and second seasons, respectively.

Using the mixture of the three manures (chicken at 2.5 m3plus FYM at 5 plus compost manure at $3.7 \mathrm{~m} 3$ /fed.) ranked the second in all yield and its components measurements. On the other hand, the lowest values in all measured yield and its components traits were recorded in case of using FYM at a rate of $15 \mathrm{~m} 3 / \mathrm{fed}$. and mineral fertilizer at $40 \mathrm{~kg} \mathrm{~N} /$ fed., without significant differences between them. Increasing lettuce yield and its components as results of chicken manure fertilization may be due to the enhancing effect of chicken manure on formation a perfect root system (Table 2) and a good vegetative growth (Table 3 ) which reflection of increasing yields and its components. Similar findings were reported by Hossain and Ryu (2017) and Masarirambi et al., (2012) on lettuce. 
Table 6. Effect of different sources of organic fertilizers on yield and its components of lettuce plants during 2016/2017 and 2017/2018 seasons.

\begin{tabular}{|c|c|c|c|c|c|c|c|c|}
\hline \multirow[b]{3}{*}{ Treatments } & \multicolumn{8}{|c|}{ Yield and its components } \\
\hline & \multicolumn{2}{|c|}{$\begin{array}{l}\text { Average head } \\
\text { F.W. / plant (g) }\end{array}$} & \multicolumn{2}{|c|}{ Yield / plot (kg) } & \multicolumn{2}{|c|}{$\begin{array}{l}\text { Total yield / } \\
\text { fed.(ton) }\end{array}$} & \multicolumn{2}{|c|}{$\begin{array}{l}\text { Yield increase over } \\
\text { control (\%) }\end{array}$} \\
\hline & $1^{\text {st }}$ season & $\begin{array}{c}2^{\text {nd }} \\
\text { season }\end{array}$ & $\begin{array}{c}1^{\text {st }} \\
\text { season }\end{array}$ & $\begin{array}{c}2^{\text {nd }} \\
\text { season }\end{array}$ & $\begin{array}{c}1^{\text {st }} \\
\text { season }\end{array}$ & $\begin{array}{c}2^{\text {nd }} \\
\text { season }\end{array}$ & $\begin{array}{c}1^{\text {st }} \\
\text { season }\end{array}$ & $\begin{array}{c}2^{\text {nd }} \\
\text { season }\end{array}$ \\
\hline $\begin{array}{l}\text { Mineral } \\
\text { fertilizer }\end{array}$ & $390.45 \mathrm{~cd}$ & $342.42 \mathrm{~d}$ & $81.994 \mathrm{~cd}$ & $71.908 d$ & $27.331 \mathrm{~cd}$ & 23.969d & 100 & 100 \\
\hline Chicken manure & 495.81a & $478.47 a$ & $104.120 \mathrm{a}$ & $100.478 \mathrm{a}$ & $34.706 a$ & $33.492 \mathrm{a}$ & 127 & 139.7 \\
\hline FYM manure & $365.02 d$ & $314.08 d$ & $76.654 d$ & $65.956 \mathrm{~d}$ & $25.551 d$ & $21.985 d$ & 93.5 & 91.7 \\
\hline $\begin{array}{l}\text { Compost } \\
\text { manure }\end{array}$ & $421.69 b c$ & $385.42 \mathrm{C}$ & $88.554 b c$ & $80.938 \mathrm{c}$ & $29.518 \mathrm{bc}$ & $26.979 c$ & 108 & 112.6 \\
\hline Mixture * & $448.14 d$ & $428.24 b$ & $94.109 \mathrm{~b}$ & $89.930 \mathrm{~b}$ & $31.369 b$ & $29.976 b$ & 114.8 & 125.1 \\
\hline
\end{tabular}

Values having the same alphabetical letter (s) did not significantly differ at 0.05 level of significance according to Duncan's multiple range test.

* Mixture (chicken manure at $2.5 \mathrm{~m}^{3}$ plus FYM at $5 \mathrm{~m}^{3}$ plus compost manure at $3.7 \mathrm{~m}^{3} / \mathrm{fed}$.)

\section{Storage experiment}

\section{Weight loss percentage:}

It is clear from the data presented in Table 7 that there was a considerable and continuous increase in weight loss percentage of stored lettuce plants when the storage period was prolonged, and the maximum loss was occurred at the end of storage period (16 days) being 1.45 and $0.44 \%$ in the first and $2^{\text {nd }}$ seasons respectively. This continuous loss in weight during storage period resulted from the loss of water by increasing transpiration and dry matter by respiration on lettuce plants. Similar results were obtained by Bardisi et al. (2013) and Shehata et al. (2012) on lettuce.

Concerning treatments; It is obvious from the data presented in Table 7 that application lettuce plants with the mixture of the three manures (chicken at $2.5 \mathrm{~m}^{3}$ plus FYM at 5 plus compost manure at $3.7 \mathrm{~m}^{3} / \mathrm{fed}$.) significantly decreased weight loss percentage of lettuce plants as compared to other treatments, the weight loss percentage reached 0.54 and $0.35 \%$ in the first and $2^{\text {nd }}$ seasons, respectively, while fertilization lettuce plants with chicken manure ranked the second in weight loss percentage which recorded 0.73 and $0.38 \%$ in the first and second seasons, respectively. These results may be due to organic manure could increase dry matter, potassium and phosphorus in the lettuce plants (Masarirambi et al., 2010) which depressed the respiration rate. Besides potassium increased osmotic potential in the 
cells of fruits (Gardener, 1985) which diminished water loss in eggplant fruit during storage, and consequently retarded fresh weight loss. Similar results were obtained by El-Sheikh and Salama (1997) on tomato, which showed that chicken manure reduced weight loss and decay percentages of tomato fruits during storage.

On the contrary, fertilization lettuce plants with mineral fertilizers significantly increased weight loss percentage of lettuce plants during storage period. The increasing in weight loss percentage of lettuce plants due to application of mineral fertilizers may be owed to the high content of moisture in plants.

Regarding the effect of interaction between different sources of fertilizers and storage period, the results in Table 7 show that the highest values of weight loss percentage were recorded from lettuce plants which fertilized with mineral fertilizers at the end of storage period ( 16 days) which gave 1.82 and $0.50 \%$ in the first and $2^{\text {nd }}$ seasons, respectively, on contrast, the lowest values of weight loss percentage at the end of storage period were occurred in a case of application lettuce plants with the mixture of the three manures that gave 0.97 and $0.38 \%$ at the same period in the first and second seasons, respectively. These results were true in the two seasons and are in agreement with those of Abd El-Rahman and Hosny (2001) on eggplant fruits and Masarirambi et al., (2010) on red lettuce.

Table 7. Effect of different sources of organic fertilizers on weight loss percentage of lettuce plants during storage period in 2017 and 2018 seasons.

\begin{tabular}{|l|c|c|c|c|c|}
\hline \multirow{2}{*}{$\begin{array}{l}\text { Growth } \\
\text { Treatments }\end{array}$} & \multicolumn{5}{c|}{ Storage period in days } \\
\cline { 2 - 6 } & $\mathbf{4}$ & $\mathbf{8}$ & $\mathbf{1 2}$ & $\mathbf{1 6}$ & Means \\
\cline { 2 - 6 } & \multicolumn{5}{|c|}{ Season 2016/2017 } \\
\hline Mineral fertilizer & $0.87 \mathrm{f}$ & $1.12 \mathrm{e}$ & $1.54 \mathrm{~b}$ & $1.82 \mathrm{a}$ & $0.88 \mathrm{a}$ \\
\hline Chicken manure & $0.42 \mathrm{j}-\mathrm{I}$ & $0.74 \mathrm{~g}$ & $0.95 \mathrm{f}$ & $1.32 \mathrm{c}$ & $0.86 \mathrm{~d}$ \\
\hline FYM manure & $0.75 \mathrm{~g}$ & $0.90 \mathrm{f}$ & $1.30 \mathrm{~cd}$ & $1.61 \mathrm{~b}$ & $0.91 \mathrm{~b}$ \\
\hline Compost manure & $0.62 \mathrm{hi}$ & $0.87 \mathrm{f}$ & $1.20 \mathrm{de}$ & $1.51 \mathrm{~b}$ & $1.05 \mathrm{c}$ \\
\hline Mixture * & $0.32 \mathrm{~lm}$ & $0.52 \mathrm{ij}$ & $0.71 \mathrm{gh}$ & $0.97 \mathrm{f}$ & $0.63 \mathrm{e}$ \\
\hline Means & $0.56 \mathrm{~d}$ & $0.83 \mathrm{c}$ & $1.14 \mathrm{~b}$ & $1.45 \mathrm{a}$ & - \\
\hline & \multicolumn{5}{|c|}{ Season 2017/2018 } \\
\hline Mineral fertilizer & $0.42 \mathrm{~b}-\mathrm{g}$ & $0.45 \mathrm{a}-\mathrm{d}$ & $0.47 \mathrm{ab}$ & $0.50 \mathrm{a}$ & $0.46 \mathrm{a}$ \\
\hline Chicken manure & $0.37 \mathrm{~h}-\mathrm{k}$ & $0.37 \mathrm{~g}-\mathrm{k}$ & $0.40 \mathrm{e}-\mathrm{i}$ & $0.42 \mathrm{c}-\mathrm{g}$ & $0.39 \mathrm{c}$ \\
\hline FYM manure & $0.40 \mathrm{~d}-\mathrm{i}$ & $0.42 \mathrm{~b}-\mathrm{g}$ & $0.45 \mathrm{~b}-\mathrm{e}$ & $0.47 \mathrm{a}-\mathrm{c}$ & $0.42 \mathrm{~b}$ \\
\hline Compost manure & $0.38 \mathrm{~g}-\mathrm{k}$ & $0.39 \mathrm{f}-\mathrm{j}$ & $0.42 \mathrm{c}-\mathrm{h}$ & $0.44 \mathrm{~b}-\mathrm{f}$ & $0.44 \mathrm{c}$ \\
\hline Mixture * & $0.33 \mathrm{kl}$ & $0.35 \mathrm{j}-\mathrm{I}$ & $0.37 \mathrm{i}-\mathrm{k}$ & $0.38 \mathrm{~g}-\mathrm{k}$ & $0.36 \mathrm{~d}$ \\
\hline Means & $0.38 \mathrm{bc}$ & $0.40 \mathrm{~b}$ & $0.42 \mathrm{a}$ & $0.44 \mathrm{a}$ & - \\
\hline
\end{tabular}

Values having the same alphabetical letter (s) did not significantly differ at 0.05 level of significance according to Duncan's multiple range test.

* Mixture (chicken manure at $2.5 \mathrm{~m}^{3}$ plus FYM at $5 \mathrm{~m}^{3}$ plus compost manure at $3.7 \mathrm{~m}^{3} / \mathrm{fed}$.)

\section{General appearance (GA)}

General appearance (GA) included vegetative defects which occur in lettuce plants during storage period such as wilting and leaf discoloration. Concerning storage period, it is clear from the data presented in Table (8) that there was significant 
decrease in general appearance of lettuce plants when the storage period was prolonged for all treatments, while the minimum values were occurred at the end of storage period (16 days). Generally, general appearance of lettuce plants began to deteriorate in all tested treatments after 12 days from storage. Obtained results were similar to those reported by Shehata et al. (2012) on lettuce.

As for treatments, the same data in Table (8) show that fertilization lettuce plants with the mixture of three manures (chicken plus FYM plus compost manure) led significantly to the highest generalappearance of lettuce plants when compared to the other treatments followed by chicken manure without significant differences between them in both seasons of study.

On the contrary, the rate of decrement in general appearance was significantly the highest in plants that fertilized with mineral fertilizer. The decreasing in general appearance of lettuce plants due to application of mineral fertilizers may be owed to the high content of moisture in plants.

Regarding the effect of interaction, results in Table 8 show that the lowest values of general appearance were recorded from lettuce plants that fertilized with mineral fertilizer at the end of storage period (16 days) which recorded 1.00 and 3.67 in the first and 2nd seasons, respectively, on the other side, the best values of GA at the end of storage period were occurred in case of fertilization lettuce plants with the mixture of three manures which gave good appearance at the after 16 days of storage in both seasons of study.

Table 8. Effect of different sources of organic fertilizers on general appearance of lettuce plants during storage period in 2017 and 2018 seasons.

\begin{tabular}{|c|c|c|c|c|c|c|}
\hline \multirow{3}{*}{$\begin{array}{l}\text { Growth } \\
\text { Treatments }\end{array}$} & \multicolumn{6}{|c|}{ Storage period in days } \\
\hline & Start & 4 & 8 & 12 & 16 & Means \\
\hline & \multicolumn{6}{|c|}{ Season $2016 / 2017$} \\
\hline Mineral fertilizer & $9.00 a$ & $9.00 a$ & 5.67de & $3.00 \mathrm{~g}$ & $1.00 \mathrm{~h}$ & $5.53 d$ \\
\hline Chicken manure & $9.00 a$ & $9.00 a$ & $8.33 a b$ & $7.67 a-c$ & 5.67de & 7.93ab \\
\hline FYM manure & $9.00 \mathrm{a}$ & $9.00 \mathrm{a}$ & $7.00 \mathrm{~b}-\mathrm{d}$ & $5.00 \mathrm{ef}$ & $3.67 \mathrm{fg}$ & $6.73 c$ \\
\hline Compost manure & $9.00 a$ & $9.00 a$ & $7.67 a-c$ & $6.33 c-e$ & 5.00ef & $7.40 \mathrm{bc}$ \\
\hline Mixture * & $9.00 a$ & $9.00 \mathrm{a}$ & $9.00 \mathrm{a}$ & $8.33 a b$ & $7.00 \mathrm{~b}-\mathrm{d}$ & $8.47 a$ \\
\hline \multirow[t]{2}{*}{ Means } & $9.00 a$ & $9.00 a$ & $7.53 b$ & $6.07 c$ & $4.47 d$ & - \\
\hline & \multicolumn{6}{|c|}{ Season $2017 / 2018$} \\
\hline Mineral fertilizer & $9.00 a$ & $9.00 a$ & $7.00 \mathrm{c}$ & $5.67 d$ & $3.67 e$ & $6.87 d$ \\
\hline Chicken manure & $9.00 \mathrm{a}$ & $9.00 \mathrm{a}$ & $9.00 \mathrm{a}$ & 8.33ab & $7.00 \mathrm{c}$ & $8.47 a b$ \\
\hline FYM manure & $9.00 a$ & $9.00 a$ & $7.67 \mathrm{bc}$ & $7.00 \mathrm{c}$ & $5.00 \mathrm{~d}$ & $7.53 c$ \\
\hline Compost manure & $9.00 \mathrm{a}$ & $9.00 \mathrm{a}$ & $8.33 a b$ & $7.67 \mathrm{bc}$ & $5.67 d$ & $7.93 \mathrm{bc}$ \\
\hline Mixture $(2+3+4)$ & $9.00 \mathrm{a}$ & $9.00 \mathrm{a}$ & $9.00 \mathrm{a}$ & $9.00 a$ & $7.67 \mathrm{bc}$ & $8.73 a$ \\
\hline Mixture * & $9.00 a$ & $9.00 a$ & $8.20 \mathrm{~b}$ & $7.53 c$ & $5.80 \mathrm{~d}$ & - \\
\hline
\end{tabular}




\section{Chlorophyll content:}

Data presented in Table (9) show a progressive and a significant decrease happened in chlorophyll content as the storage period was prolonged, where the maximum chlorophyll content was occurred at harvesting time, the minimum values were occurred at the end of storage period (16 days). Generally, lettuce plants became yellowish green with the extension of the storage period.

The reduction in chlorophyll content with the elapse of storage period may be due to the destruction of the chlorophyll and transformation of chloroplasts to chromoplasts by chlorophyllase activity (Hulme, 1970). These results are in agreement with those obtained by Shehata et al. (2012) on lettuce who found that chlorophyll reading in different plant organs decreased gradually with the prolongation of storage period.

Regarding treatments, it is clear from the same results in Table (9) that fertilization of lettuce plants with the mixture of the three manures (chicken manure plus FYM plus compost manure) significantly increased chlorophyll content of lettuce plants as compared to other treatments, the chlorophyll means all over the storage period were 41.02 and 43.02 SPAD in the first and second seasons, respectively, while using chicken manure ranked the second in chlorophyll means were 36.02 and 37.5 SPAD in first and $2^{\text {nd }}$ seasons, respectively.

Table 9. Effect of different sources of organic fertilizers on chlorophyll content (SPAD) of lettuce plants during storage period in 2017 and 2018 seasons.

\begin{tabular}{|l|c|c|c|c|c|c|}
\hline \multirow{2}{*}{ Growth } & \multicolumn{7}{c|}{ Storage period in days } \\
\cline { 2 - 8 } & Start & $\mathbf{4}$ & $\mathbf{8}$ & $\mathbf{1 2}$ & $\mathbf{1 6}$ & Means \\
\cline { 2 - 8 } & \multicolumn{7}{|c|}{ Season $\mathbf{2 0 1 7}$} \\
\hline Mineral fertilizer & $36.11 \mathrm{a}-\mathrm{g}$ & $31.30 \mathrm{~d}-\mathrm{i}$ & $28.22 \mathrm{~g}-\mathrm{j}$ & $25.31 \mathrm{ij}$ & $21.40 \mathrm{j}$ & $28.47 \mathrm{c}$ \\
\hline Chicken manure & $41.11 \mathrm{a}-\mathrm{c}$ & $38.24 \mathrm{a}-\mathrm{e}$ & $36.53 \mathrm{a}-\mathrm{f}$ & $33.11 \mathrm{c}-\mathrm{i}$ & $31.11 \mathrm{~d}-\mathrm{i}$ & $36.02 \mathrm{~b}$ \\
\hline FYM manure & $38.25 \mathrm{a}-\mathrm{e}$ & $35.50 \mathrm{~b}-\mathrm{g}$ & $33.13 \mathrm{c}-\mathrm{i}$ & $30.14 \mathrm{e}-\mathrm{i}$ & $26.21 \mathrm{~h}-\mathrm{j}$ & $32.65 \mathrm{~b}$ \\
\hline Compost manure & $39.23 \mathrm{a}-\mathrm{d}$ & $37.11 \mathrm{a}-\mathrm{e}$ & $34.21 \mathrm{c}-\mathrm{h}$ & $31.24 \mathrm{~d}-\mathrm{i}$ & $28.31 \mathrm{f}-\mathrm{j}$ & $34.02 \mathrm{~b}$ \\
\hline Mixture * & $44.35 \mathrm{a}$ & $43.25 \mathrm{ab}$ & $41.30 \mathrm{a}-\mathrm{c}$ & $39.00 \mathrm{a}-\mathrm{d}$ & $37.20 \mathrm{a}-\mathrm{e}$ & $41.02 \mathrm{a}$ \\
\hline Means & $39.81 \mathrm{a}$ & $37.08 \mathrm{ab}$ & $34.68 \mathrm{bc}$ & $31.76 \mathrm{~cd}$ & $28.35 \mathrm{~d}$ & - \\
\hline & \multicolumn{7}{|c|}{ Season 2018 } \\
\hline Mineral fertilizer & $36.41 \mathrm{c}-\mathrm{i}$ & $31.60 \mathrm{~g}-\mathrm{k}$ & $28.52 \mathrm{i}-\mathrm{I}$ & $25.61 \mathrm{kl}$ & $21.70 \mathrm{l}$ & $28.77 \mathrm{~d}$ \\
\hline Chicken manure & $42.61 \mathrm{a}-\mathrm{d}$ & $39.74 \mathrm{a}-\mathrm{g}$ & $38.03 \mathrm{~b}-\mathrm{h}$ & $34.61 \mathrm{~d}-\mathrm{j}$ & $32.61 \mathrm{f}-\mathrm{k}$ & $37.52 \mathrm{~b}$ \\
\hline FYM manure & $38.75 \mathrm{a}-\mathrm{h}$ & $36.00 \mathrm{c}-\mathrm{i}$ & $33.63 \mathrm{e}-\mathrm{k}$ & $30.64 \mathrm{~h}-\mathrm{k}$ & $26.71 \mathrm{j}-\mathrm{l}$ & $33.15 \mathrm{c}$ \\
\hline Compost manure & $40.23 \mathrm{a}-\mathrm{f}$ & $38.11 \mathrm{a}-\mathrm{h}$ & $35.21 \mathrm{c}-\mathrm{i}$ & $32.24 \mathrm{f}-\mathrm{k}$ & $29.31 \mathrm{i}-\mathrm{l}$ & $35.02 \mathrm{bc}$ \\
\hline Mixture * & $46.35 \mathrm{a}$ & $45.25 \mathrm{ab}$ & $43.30 \mathrm{a}-\mathrm{c}$ & $41.00 \mathrm{a}-\mathrm{e}$ & $39.20 \mathrm{a}-\mathrm{g}$ & $43.02 \mathrm{a}$ \\
\hline Means & $40.87 \mathrm{a}$ & $38.14 \mathrm{ab}$ & $35.74 \mathrm{bc}$ & $32.82 \mathrm{~cd}$ & $29.91 \mathrm{~d}$ & - \\
\hline
\end{tabular}

These results may be due to the different specifying of nitrogen and magnesium content in mixture manure and chicken manure more than its contents in the other treatments. This result was in line with the work of Silva et al. (2017) on lettuce plants who reported that using organic fertilizers significantly increased chlorophyll content in leaves. 
Concerning the effect of interaction, generally it is clear that the highest values of chlorophyll content at the end of storage period (16 days) were noted in case of fertilization lettuce plants with the mixture manure (37.2 and 39.2 SPAD) followed by fertilization with chicken manure (31.11 and 32.61 SPAD) in the first and second seasons, respectively.

\section{Polyphenol oxidase activity (PPO):}

Data presented in Table (10) show that there was a progressive and significantly increase in PPO activity as the storage period was extended, where the minimum values of polyphenol oxidase activity occurred at harvesting time ( 0.373 and $0.369 \%$ ) while the maximum values were occurred at the end of storage period $(0.458$ and $0.454 \%)$ in the first and second seasons, respectively. These results are in agreement with those obtained by Shehata et al. (2012) on lettuce.

Concerning treatments, it is clear from the same data in Table 10 that fertilization lettuce plants with mineralfertilizer significantly increased polyphenol oxidase activity of lettuce plants as compared to other treatments; the man of PPO activity was 0.457 and $0.455 \%$ in the first and $2^{\text {nd }}$ seasons respectively, while using farmyard manure ranked the second.

Table 10. Effect of different sources of organic fertilizers on polyphenol oxidase percent of lettuce plants during storage period in 2017 and 2018 seasons.

\begin{tabular}{|l|c|c|c|c|c|c|c|}
\hline \multirow{2}{*}{ Growth } & \multicolumn{7}{|c|}{ Storage period in days } \\
\cline { 2 - 8 } Treatments & Start & $\mathbf{4}$ & $\mathbf{8}$ & $\mathbf{1 2}$ & $\mathbf{1 6}$ & Means \\
\cline { 2 - 8 } Mineral fertilizer & $0.398 \mathrm{e}-\mathrm{i}$ & $0.431 \mathrm{~b}-\mathrm{f}$ & $0.462 \mathrm{a}-\mathrm{c}$ & $0.482 \mathrm{ab}$ & $0.510 \mathrm{a}$ & $0.457 \mathrm{a}$ \\
\hline Chicken manure & $0.362 \mathrm{~h}-\mathrm{j}$ & $0.386 \mathrm{f}-\mathrm{j}$ & $0.392 \mathrm{e}-\mathrm{j}$ & $0.420 \mathrm{c}-\mathrm{g}$ & $0.440 \mathrm{~b}-\mathrm{e}$ & $0.400 \mathrm{c}$ \\
\hline FYM manure & $0.387 \mathrm{f}-\mathrm{j}$ & $0.411 \mathrm{c}-\mathrm{h}$ & $0.432 \mathrm{~b}-\mathrm{f}$ & $0.458 \mathrm{~b}-\mathrm{d}$ & $0.477 \mathrm{ab}$ & $0.433 \mathrm{~b}$ \\
\hline Compost manure & $0.376 \mathrm{~g}-\mathrm{j}$ & $0.395 \mathrm{e}-\mathrm{i}$ & $0.413 \mathrm{c}-\mathrm{h}$ & $0.437 \mathrm{~b}-\mathrm{f}$ & $0.457 \mathrm{~b}-\mathrm{d}$ & $0.416 \mathrm{bc}$ \\
\hline Mixture * & $0.342 \mathrm{j}$ & $0.357 \mathrm{i}-\mathrm{j}$ & $0.374 \mathrm{~g}-\mathrm{j}$ & $0.395 \mathrm{e}-\mathrm{i}$ & $0.408 \mathrm{~d}-\mathrm{i}$ & $0.375 \mathrm{~d}$ \\
\hline Means & $0.373 \mathrm{c}$ & $0.396 \mathrm{bc}$ & $0.415 \mathrm{~b}$ & $0.438 \mathrm{a}$ & $0.458 \mathrm{a}$ & - \\
\hline & \multicolumn{7}{|c|}{ Season $2017 / 2018$} \\
\hline Mineral fertilizer & $0.376 \mathrm{f}-\mathrm{j}$ & $0.429 \mathrm{~b}-\mathrm{g}$ & $0.460 \mathrm{a}-\mathrm{c}$ & $0.480 \mathrm{ab}$ & $0.508 \mathrm{a}$ & $0.455 \mathrm{a}$ \\
\hline Chicken manure & $0.357 \mathrm{i}-\mathrm{k}$ & $0.381 \mathrm{~g}-\mathrm{k}$ & $0.387 \mathrm{f}-\mathrm{k}$ & $0.415 \mathrm{c}-\mathrm{h}$ & $0.435 \mathrm{~b}-\mathrm{f}$ & $0.395 \mathrm{c}$ \\
\hline FYM manure & $0.384 \mathrm{f}-\mathrm{k}$ & $0.408 \mathrm{~d}-\mathrm{i}$ & $0.429 \mathrm{~b}-\mathrm{g}$ & $0.455 \mathrm{~b}-\mathrm{d}$ & $0.474 \mathrm{ab}$ & $0.430 \mathrm{~b}$ \\
\hline Compost manure & $0.372 \mathrm{~h}-\mathrm{k}$ & $0.391 \mathrm{f}-\mathrm{j}$ & $0.409 \mathrm{c}-\mathrm{h}$ & $0.433 \mathrm{~b}-\mathrm{f}$ & $0.453 \mathrm{~b}-\mathrm{e}$ & $0.412 \mathrm{bc}$ \\
\hline Mixture * & $0.336 \mathrm{k}$ & $0.351 \mathrm{jk}$ & $0.368 \mathrm{~h}-\mathrm{k}$ & $0.389 \mathrm{f}-\mathrm{j}$ & $0.402 \mathrm{e}-\mathrm{j}$ & $0.369 \mathrm{~d}$ \\
\hline Means & $0.369 \mathrm{c}$ & $0.392 \mathrm{bc}$ & $0.411 \mathrm{~b}$ & $0.434 \mathrm{a}$ & $0.454 \mathrm{a}$ & - \\
\hline
\end{tabular}

Values having the same alphabetical letter (s) did not significantly differ at 0.05 level of significance according to Duncan's multiple range test.

* Mixture (chicken manure at $2.5 \mathrm{~m}^{3}$ plus FYM at $5 \mathrm{~m}^{3}$ plus compost manure at $3.7 \mathrm{~m}^{3} / \mathrm{fed}$.)

On contrast, the lowest mean values of polyphenol oxidase activity occurred in case of fertilization with the mixture of the three manures which recorded 0.375 and $0.369 \%$ in both seasons, respectively.

Regarding the effect of interaction, the same results in Table 10 show that, the lowest values of PPO activity were recorded from lettuce plants which fertilized with the mixture of the three manures (chicken manure plus FYM plus compost 
manure) at the beginning of storage period whilst, the highest values were at the end of storage period ( 16 days) in case of fertilization with mineral fertilizer.

\section{Total phenolic contents:}

Data presented in Table (11) show that total phenolic contents increased at the beginning of the storage period then dramatically decreased at the end of storage period (16 days).

The decrease of this content is probably due to the oxidation by PPO (Shehata et al. 2012), it is also reported that, quercetin was oxidized directly by PPO. Moreover, Robards et al. (1999) found that the role of phenolic compounds in processing of oxidation as antioxidants and as substrates in browning reaction. Obtained results were similar to those reported by Shehata et al. (2012) on lettuce.

Table 11. Effect of different sources of organic fertilizers on total phenolic contents ( $\mathrm{mg} / 100 \mathrm{~g}$ f.w) of lettuce plants during storage period in 2017 and 2018 seasons.

\begin{tabular}{|l|c|c|c|c|c|c|}
\hline \multirow{2}{*}{ Growth } & \multicolumn{7}{c|}{ Storage period in days } \\
\cline { 2 - 7 } Treatments & Start & $\mathbf{4}$ & $\mathbf{8}$ & $\mathbf{1 2}$ & $\mathbf{1 6}$ & Means \\
\cline { 2 - 7 } & \multicolumn{7}{|c|}{ Season 2016/2017 } \\
\hline Mineral fertilizer & $12.50 \mathrm{hi}$ & $11.70 \mathrm{k}$ & $11.00 \mathrm{mn}$ & $10.06 \mathrm{p}$ & $9.01 \mathrm{q}$ & $10.35 \mathrm{e}$ \\
\hline Chicken manure & $13.90 \mathrm{~b}$ & $13.02 \mathrm{ef}$ & $12.70 \mathrm{~g}$ & $12.00 \mathrm{j}$ & $10.90 \mathrm{n}$ & $12.50 \mathrm{~b}$ \\
\hline FYM manure & $13.30 \mathrm{~d}$ & $12.60 \mathrm{gh}$ & $11.90 \mathrm{j}$ & $11.10 \mathrm{~m}$ & $10.10 \mathrm{p}$ & $11.80 \mathrm{~d}$ \\
\hline Compost manure & $13.60 \mathrm{c}$ & $12.90 \mathrm{f}$ & $12.55 \mathrm{~g}-\mathrm{i}$ & $11.70 \mathrm{k}$ & $10.60 \mathrm{o}$ & $12.27 \mathrm{c}$ \\
\hline Mixture * & $14.22 \mathrm{a}$ & $13.68 \mathrm{c}$ & $13.20 \mathrm{de}$ & $12.40 \mathrm{i}$ & $11.40 \mathrm{l}$ & $12.98 \mathrm{a}$ \\
\hline Means & $13.50 \mathrm{a}$ & $12.78 \mathrm{~b}$ & $12.27 \mathrm{c}$ & $11.45 \mathrm{~d}$ & $10.40 \mathrm{e}$ & - \\
\hline & \multicolumn{7}{|c|}{ Season $\mathbf{2 0 1 7 / 2 0 1 8}$} \\
\hline Mineral fertilizer & $13.50 \mathrm{~h}$ & $12.70 \mathrm{j}$ & $12.00 \mathrm{l}$ & $11.06 \mathrm{n}$ & $10.01 \mathrm{o}$ & $11.85 \mathrm{e}$ \\
\hline Chicken manure & $14.93 \mathrm{~b}$ & $14.05 \mathrm{e}$ & $13.73 \mathrm{fg}$ & $13.03 \mathrm{i}$ & $11.93 \mathrm{l}$ & $13.53 \mathrm{~b}$ \\
\hline FYM manure & $14.31 \mathrm{~d}$ & $13.61 \mathrm{gh}$ & $12.91 \mathrm{i}$ & $12.11 \mathrm{l}$ & $11.11 \mathrm{n}$ & $12.81 \mathrm{~d}$ \\
\hline Compost manure & $14.61 \mathrm{c}$ & $13.91 \mathrm{ef}$ & $13.56 \mathrm{gh}$ & $12.71 \mathrm{j}$ & $11.61 \mathrm{~m}$ & $13.28 \mathrm{c}$ \\
\hline Mixture * & $15.27 \mathrm{a}$ & $14.73 \mathrm{c}$ & $14.25 \mathrm{~d}$ & $13.45 \mathrm{~h}$ & $12.45 \mathrm{k}$ & $14.03 \mathrm{a}$ \\
\hline Means & $14.52 \mathrm{a}$ & $13.80 \mathrm{~b}$ & $13.29 \mathrm{c}$ & $12.47 \mathrm{~d}$ & $11.42 \mathrm{e}$ & - \\
\hline
\end{tabular}

Values having the same alphabetical letter (s) did not significantly differ at 0.05 level of significance according to Duncan's multiple range test.

* Mixture (chicken manure at $2.5 \mathrm{~m}^{3}$ plus FYM at $5 \mathrm{~m}^{3}$ plus compost manure at $3.7 \mathrm{~m}^{3} / \mathrm{fed}$.)

As for treatments, it is obvious from the same data in Table 11 that application lettuce plants with the mixture of the three manures (chicken at 2.5 $\mathrm{m}^{3}$ plus FYM at 5 plus compost manure at $3.7 \mathrm{~m}^{3} / \mathrm{fed}$.) significantly increased total phenolic content of lettuce plants as compared to other treatmentswhile chicken manure ranked the second in this respect.

The interaction between different sources of fertilization and storage period was significant; however the lowest values of total phenolic contents were at the end of storage period ( 16 days) in plants fertilized with mineral fertilizers. While thehighest ones of this compound was found in lettuce plants treated with the mixture of the three manures (chicken at $2.5 \mathrm{~m}^{3}$ plus FYM at 5 plus compost manure at $3.7 \mathrm{~m}^{3} / \mathrm{fed}$.), these results hold true in both seasons of study. 


\section{CONCLUSION}

From the previous results of this investigation, it could be concluded that fertilization lettuce plants with chicken manure $\left(7.5 \mathrm{~m}^{3} / \mathrm{fed}\right.$.) or with the mixture of chicken at $2.5 \mathrm{~m}^{3}$ plus FYM at 5 plus compost manure at $3.7 \mathrm{~m}^{3} / \mathrm{fed}$., were the superior treatments for produce the best values of vegetative growth parameters, fresh and dry weight per plant organs, root system, nitrate content and yield of lettuce plants. These treatments also reduced weight loss percentage and PPO activity, maintained chlorophyll and total phenolic contents and gave lettuce plants with good appearance after 12 days at $0^{\circ} \mathrm{C}$ and $90-95 \% \mathrm{RH}$. for chicken manure and after 16 days for the mixture treatment.

\section{REFERENCES}

1. Abd El-Rahman S.Z. and F. Hosny. 2001. Effect of organic and inorganic fertilizers on growth, yield, fruit quality and storability of eggplant. J. Agric. Sci. Mansoura Univ., 26(10): 6307-6321.

2. Ahmed, A.M.A. 2013. Effect of humic acid application as well as bio and mineral phosphorus fertilization on growth, green pods, dry seed yield and quality of peas (Pisum sativum $L$ ) under the newly reclaimed soil conditions. Egypt. J. Appl. Sci. 28(7):338-360.

3. Arisha, H.M.E., K.A.M. Nour and F.M.A. El-Saadony. 2015. Comparative study on antioxidants and synthetic plantgrowth regulators effects for reducing flower shedding, enhancing yield in relation to leafanatomicalstructure of pepperplant. The $2^{\text {nd }}$ international conference on horti. Crops 15-18 Mrch 103-123.

4. Bardisi, A., M.A. Mandour and O.O. Mohamed. 2013. Growth, yield and storability of lettuce as affected by foliar spray with some organic compounds under sandy soil conditions. Zagazig J. Agric. Res., 40 (6): 1083-1092.

5. Cafado, D.A., M. Haroon, L.E. Sharderand and V.L. Youn. 1975. Rapid colorimetric determination of nitrate in plant tissues by nitrification of salicylic acid comm. Soil and plant Anal., 6:71-80.

6. Dogăn, M.; O. Aslan and S. Dogăn. 2002. Substrate specificity, heat inactivation and inhibition of polyphenol oxidase from different aubergine cultivars.Intern. J. Food Sci. and Technol., 37:415-423.

7. El-Sheikh, T.M. and G.M. Salama. 1997. Influence of chicken manure on growth, yield, fruit quality and storability of tomatoes. Annals of Agric. Sci. Moshtohor, 35(4): 2391-2413.

8. Gardener, F.P.; R.B. Pearce and R.L. Michel. 1985. Physiology of crop plants. The low a State University press pp. 327.

9. Hossain, M.B. and K.S. Ryu. 2017. Effects of organic and inorganic fertilizers on lettuce (lactuca sativa L.) and soil properties. SAARC J. Agri., 15(2): 93-102. 
10. Hsieh, C.F. and K.N. Hsu. 1993. An experiment on the organic farming of sweet corn and vegetable soybeans. Bulletin of Taichung District Agricultural Improvement Station, No. 39:59-84.

11. Hulme, A.C. 1970. The biochemistry of fruit and their products. Academic Press London and New York.Vol.1.

12. Masarirambi, M.T., P. Dlamini, P.K. Wahome and T.O. Oseni. 2012. Effects of chicken manure on growth, yield and quality of lettuce (Lactuca sativa L.) 'Taina' under a lath house in a semi-arid sub-tropical environment. Am-Euras. J. Agric. \& Environ. Sci., 12 (3): 399-406.

13. Masarirambi, M.T.; M.M. Hlawe; O.T. Oseni1 and T.E. Sibiya. 2010. Effects of organic fertilizers on growth, yield, quality and sensory evaluation of red lettuce (Lactuca sativa L.) 'VenezaRoxa'. Agric. Biol. J. N. Am., 1(6):1319-1324.

14. Melese, W. 2016. Effect of farm yard manure application rate on yield and yield components of lettuce (Lactuca sativa) at jimma southwestern Ethiopia. International J. Res. - Granthaalayah.4 (Iss.8): 75-83.

15. Rather, A.M.; N. Jabeen; T.A. Bhat; E.A. Parray; M.A. Hajam; M.A. Wani and I.A Bhat. 2018. Effect of organic manures and bio-fertilizers on growth and yield of lettuce. The Pharma Innovation J., 7(5): 75-77.

16. Reis, M.; L. Coelho; J. Beltrão; I. Domingos and M. Moura. 2014. Comparative effects of inorganic and organic compost fertilization on lettuce (Lactuca sativa L.). International J. of energy and environment 8:137-146.

17. Reynders, L. and K. Vlassak. 1982. Use of Azospirillum brasilense as biofertilizer in intensive wheat cropping. Plant and Soil 66:217-223.

18. Robards, K.; P.D. Prenzle; G. Tucker, P. Swatsitang and W. Solver. 1999. Phenolic compounds and their role in oxidative processes in fruits. Food Chemistry, 66(4): 401-436.

19. Shehata, S.A.; T.M. El-Sheikh; M. El. Mohamed and M.A. Saleh. 2012. Effect of some pre- and postharvest treatments on browning inhibition in fresh cut lettuce during cold storage. J. Appl. Sci. Res., 8(1): 25-33.

20. Silva, A.F.T.; R.C. Avelino; L.P.S. Brito; J.C.R. Anjos; J.V.S. Júnior; M.Z. Beckmann-Cavalcante. 2017. Growth and yield of lettuce cultivars under organic fertilization and different environments. Com. Sci., Bom Jesus, v.8, n.2, p. 265274.

21. Snedecor, C.W. and W.G. Cochran. 1982. Statistical Methods. $7^{\text {th }}$ Ed. The lowa state Univ. Press.Ames. lowa, USA. 325-330.

22. Velioglu, Y.S.; Mazza, G.; L. Gao and B.D. Oomah. 1998. Antioxidant activity and total phenolics in selected fruits, vegetables, and grain products. J. Agric. Food \& Chemistry 46:113-4117. 


\section{تأثثير مصادر مختلفة من الأسمدة العضوية على النمو

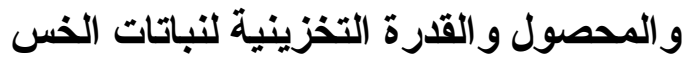

\section{أميمه عثمان محمد1 ، محمود عاطف صالح1 و منال عبد الحميد مندور2 \\ 1- قسم بحوث تداول الخضر - معهد بحوث البساتين - مركز البحوث الزراعية ـ مصر. 2- المعل المركزى للزرراعة العضوية ـ مركز البحوث الزر اعية ـ مصر.}

أجريت هذه الدر اسة خلال الموسم الشتوى لعامى 2017/2016 ، 2018/2017 بمزر عة التجارب

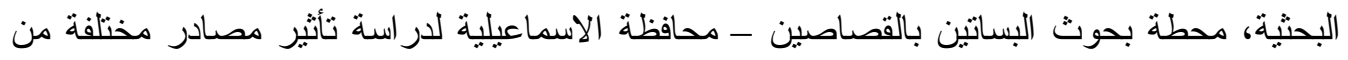

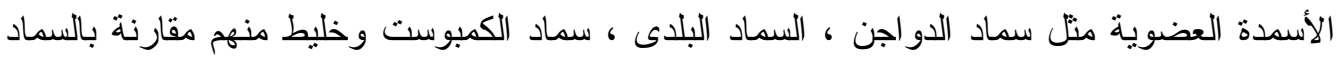

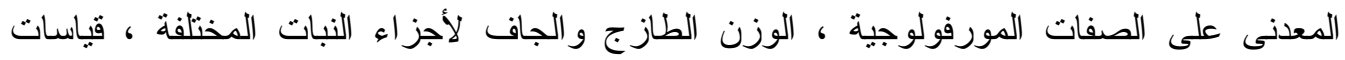

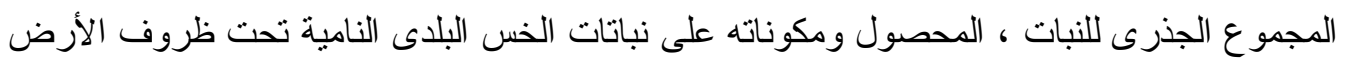

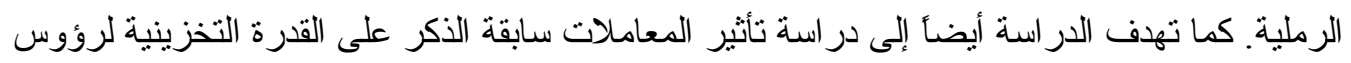

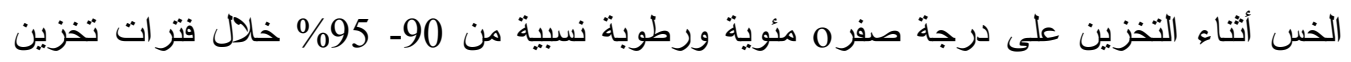
مختلفة (صفر ، 4، 8، 12 ، 16 يو ماء).

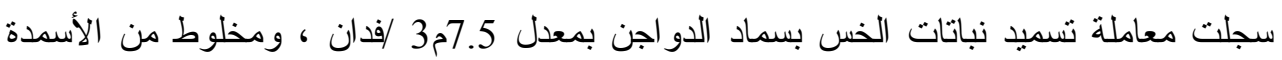

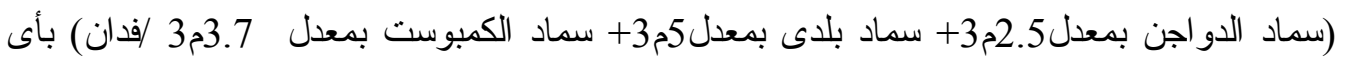

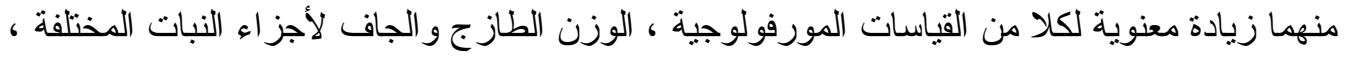

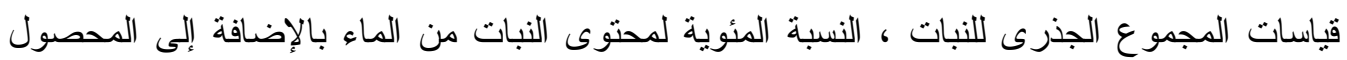

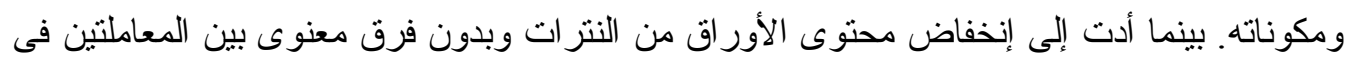
معظم الحالات. كما اوضحت النتائج أن استخدام سماد الخليط ( سماد الدو اجن بمعدل2.5م3+ سماد بلدى بمعدل5م3+ سماد الكمبوست بمعدل 3.733 /فدان) أو سماد الدواجن قد أدى إلى تحسين القدرة التخزينية لنباتات

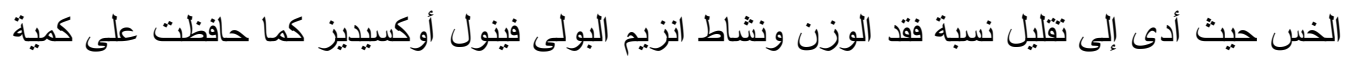
الكلوروفيل و الفينو لات الكلية أثناء التخزين وأعطت نباتات ذات ذات مظهر جيد بعد 12 يوم من التخزين للمعاملة سماد الدو اجن وبعد 16 يوم للمعاملة بالخليط. 

VEGETATIVE GROWTH, YIELD AND STORABILITY OF LETTUCE PLANTS 